Sobhy Bey and Sayed Eisa described a case of bilateral tuberculosis of the conjunctiva and lacrymal glands. Tewfik gave a useful resumé of the method of preparation of the patient for cataract operation, though he omitted the important step of effecting retrobulbar anaesthesia. He also made the useful suggestion of treating post-operative lagophthalmos by Thierschgrafting. Sobhy Bey reported a case of angioid streaks in the retina, also a case of syphilitic inflammation of the central artery of the retina. Zaky treated a case of sympathetic ophthalmitis, after excision of the blind sympathizing eye, with increasing doses of sodium salicylate until the patient was taking 21 grammes a day. The vision improved from $2 / 60$ to $6 / 18$, with correction.

\title{
$\overline{\overline{ }}$ \\ CORRESPONDENCE
}

To the Editor of ThE British Journal of Ophthalmology

SIr,-Knowing the erudition with which your journal is conducted, I would very much value your opinion on a small matter of pedantry.

We know that medical men are very lax in their use of the English language, and we witness glaring examples of it from time to time, such as the use of the expression "the acute abdomen." It passes the wit of the ordinary man to understand how any portion of the body with so much rotundity as the abdomen can be called "acute," but, from the context, we gather that the users of the term refer to some inflammatory or other acute ailment affecting the abdominal cavity. I regret to see that a similar looseness of expression has crept into ophthalmic literature, for I lately received a notice announcing a discussion on "macula colobomata." It seems to me we have here two nouns, one in the singular and the other in the plural. Surely macula should either be in the genitive case or should be converted into an adjectival form. I should be glad to have the pronouncement of the erudite member of your staff on the subject.

Yours faithfully,

November 17, 1926.

"Pedant.",

[We sympathize with "Pedant" in this matter and have no hesitation in offering our opinion that he is right in his contention. The classical scholar, who deplored the fact that medical Latin 
barked at the best of times, might have waxed as eloquent over much of the medical English. It is to be feared that the authors of the King's English would find innumerable examples in our pages to illustrate the common faults in grammar and composition; this is largely due, in our opinion, to the fact that most people write as they would speak. We have heard one who prides himself on his English, split the infinitive in speech, a thing he would never have done in cold print. May we, in return, ask "Pedant" whether he is quite correct in writing of an "acute ailment affecting the abdominal cavity"; does he not mean to refer to the contents of the said cavity?-EDITORs.]

\section{NOTES}

Among the elections to the Council of the The Royal Society Royal Society for the ensuing year we are pleased to see the name of Sir John Parsons.

The Paul Philip Reitlinger Prize for 1926 of Prize the University of London has been awarded to Mr. Stewart Duke-Elder for his essay on "The Ocular Circulation: its Normal Pressure Relationships and their Physiological Significance," which was published in this journal, October, 1926.

Dr. J. A. Vallentine has been appointed Hon. Appointment Ophthalmic Surgeon to the Royal West Sussex Hospital, Chichester.

The Model Student's

Coulton, in his "Social Life in Britain from Eye Strain and its Cause the Conquest to the Reformation," gives the following excerpt from Trevisa's "Higden," VIII, 217, which deals with the model student: "In his childhood he lernede his gramere and was so disesed with the heedache that he hadde non hope to spede afterward in lore. His moder spak to hym and seide, 'Sone,' I trowe that the lewednesse and unsemeliche 